\title{
Power Generation from Coal-A review
}

\author{
Mridul Sarker, Debasish Chowdhury, Iqbal Hossain* \\ Department of Chemical Engineering, Bangladesh University of Engineering \& Technology, \\ BUET, Dhaka-1000.
}

\begin{abstract}
Power generation from coal is an essential need to meet world's energy demand. There are two major challenges in coal-based power generation: improving the efficiency and reducing the emissions level. In fact, these challenges have been under research for a long time. This article focuses on the recent developments of process technologies and coal treatment to improve the performance of coal-based power plant. Barriers to the adoptions of modern developments and additional needs in research are also addressed.
\end{abstract}

\section{INTRODUCTION}

Coal is the world's most abundant and widely distributed fossil fuel, with global proven reserves totaling nearly 1000 billion tons. Given these characteristics, coal has been a key component of the electricity generation mix worldwide. Coal fuels more than $40 \%$ of the world's electricity, though this figure is much higher in many countries, such as South Africa $(93 \%)$, Poland (92\%), China (79\%), India (69\%) and the United States (49\%). Moreover, the growing energy needs of the developing world are likely to ensure that coal remains a key component of the power generation mix in the foreseeable future, regardless of climate change policy. The main objective of this article is to review the major ongoing developments in process technology, barriers to the adoption of technology, and further research requirement relevant to power generation from coal on the basis of the most recent (2011) report from International Energy Agency (IEA).

\section{DEVELOPMENTS IN PROCESS TECHNOLOGY}

Employing the combustion of pulverized coal in air to raise steam has been the mainstay of coal-based power generation worldwide for almost 100 years. The efficiency of a pulverized coal combustion unit depends on a variety of factors: steam conditions, the quality of coal used, ambient conditions, plant design, and operational and maintenance practice. A number of advanced coal-fired power generation technologies, cleaner coal technologies (CCTs), as they are often called, have been or are being developed to improve thermal efficiency, to reduce and capture $\mathrm{CO}_{2}$ emissions, and to reduce other emissions (e.g. NOx, $\mathrm{SO}_{2}$ and particulates). The major coal-based power generation technologies available today, and/or under development, include supercritical (SC) and ultra-supercritical (USC) pulverized coal combustion, circulating fluidized bed combustion (CFBC), and Integrated gasification combined cycle (IGCC).

\footnotetext{
* Corresponding Author: Iqbal Hossain,
}

E-mail: iqbalhossain@che.buet.ac.bd

\subsection{Supercritical and Ultra-Supercritical Pulverized Coal-Fired Technology}

Supercritical is a thermodynamic expression where there is no difference between the liquid and gaseous phase. Water/steam reaches this state at about 22.1 MPa (221 bar) pressure. Above this operating pressure of the steam, the cycle is supercritical and its cycle medium is a single-phase fluid; as a result there is no need to separate water from steam as in the boiler of a sub-critical cycle.

Typical sub-critical steam cycle operating parameters are from 150 to 180 bar pressure and between $540^{\circ} \mathrm{C}$ and $565^{\circ} \mathrm{C}$ temperature for superheated steam, with reheat to similar temperatures. Steam cycle operating parameters for super critical plants typically are 245 bar pressure and 540 to $570^{\circ} \mathrm{C}$ for superheated steam, with reheat to similar temperatures. Ultra-supercritical units operating at temperatures of $700^{\circ} \mathrm{C}$ and higher, and pressure in excess of 300 bar are in the development phase. Once-through boilers are therefore used in a supercritical cycle. A switch from sub-critical to current USC steam conditions would raise efficiency by around 4 to 6 percentage-points. USC plants will reduce fuel consumption and emissions by 25 to $30 \%$ compared to the current state-of-the-art sub-critical cycle $^{[3]}$. Boiler and steam turbine costs can be as much as 40 to $50 \%$ higher for a USC plant than for a sub-critical plant.

Ultra-supercritical units use nickel-based super-alloys for some components in the boiler, turbine and piping. Such materials are used in gas turbines. However, the balance-of-plant cost can be 13 to $16 \%$ lower, because of reductions in coal consumption, coal handling and flue gas handling. The total investment cost for USC steam cycle plants can be 12 to $15 \%$ higher than the cost of a subcritical steam cycle. Adding $\mathrm{CO}_{2}$ capture to a power plant results in a substantial energy penalty. As large volumes of absorbent are required to treat the flue gas, its subsequent regeneration uses considerable quantities of low pressure steam that would otherwise 
be available for power generation. Maximizing plant efficiency is, therefore, highly desirable when employing carbon capture and storage: the higher the net efficiency of the base plant, the higher will be the net efficiency of that plant with carbon capture and storage. However, the operating environment with flue gas from coal is different so international programs are seeking to develop the necessary materials and fabrication methods for use with these materials.

Difficulties for adaptation of supercritical and ultra-supercritical units: Supercritical and ultrasupercritical technology is sometimes rejected or overlooked because of misguided perceptions that they are costly, unproven and unsuitable for use with local coals. Consequently, many countries have preferred conventional sub-critical technology despite evidence that demonstrates that SC and USC designs are commercially proven and competitive, especially when coal prices are high. Experience is lacking only in the case of high-ash coals; but even for such coals, there should be a gradual switch from sub-critical to SC and then to USC as operational experience grows. The major barriers to advances in SC and USC steam cycles are therefore technical, i.e. metallurgical and material fabrication issues. Apart from the continued development of materials, fabrication methods and long-duration testing of materials, there is clearly a need to accelerate the development and full-scale demonstration of advanced USC conditions.

Location of SC and USC units: Supercritical plants are currently located in eighteen countries. Globally between 2004 and mid-2007, the share of SC plants increased from approximately 18 to $20 \%$ ( $265 \mathrm{GW})$ of coal-fired capacity. This rose to over $25 \%$ in 2009 and increased further as new SC units were built in China, India, South Africa and Russia.

USC plants are in operation in Denmark, Germany, Japan and Italy; however their share of global power generation is under $1 \%$. A number of USC plants are also being constructed in China. An example is the Huaneng Group's Yuhuan Power plant in Zhejiang Province, which is a USC plant with two 1000 MWe units and steam parameters of 26.25 $\mathrm{MPa} / 600^{\circ} \mathrm{C} / 600^{\circ} \mathrm{C}$. Chinese manufacturers are also offering USC at up to $605^{\circ} \mathrm{C}$, i.e. at or near state-of-the-art conditions (Minchener, 2010).

While the first generation of supercritical units was under $400 \mathrm{MWe}$ in size, larger units of up to 1100 MWe are progressively being built. The major units, built under construction or under planning in different countries, clearly demonstrate the progression to larger unit sizes (Table 1).

\subsection{Circulating Fluidized Bed Combustion Technology}

There are two major categories of fluidized bed combustion units: those operating with bubbling fluidized bed combustion (BFBC) and those with circulating fluidized bed combustion (CFBC). Almost all of the recent plant additions have been CFBC units. CFBC units can tolerate a wide variety of coals and particle sizes and, because of their low operating temperatures and staged combustion, produce low levels of NOx relative to pulverized coal boilers. The lower operating temperature is also ideally suitable for the in situ capture of sulphur dioxide $\left(\mathrm{SO}_{2}\right)$. The efficiency of CFBC units is similar to that of pulverized coal units. CFBC units can demonstrate significant operating experience. They have the ability to accept a variety of fuels, including a range of coals: from lignite to anthracite, waste coal and biomass. They exhibit low emissions of conventional pollutants and show potential to be designed for oxy-firing. Though there is a need for research, development and demonstration (RD\&D) to progress to higher steam conditions over time, there are no obvious difficulties to CFBC other than the size of the market.

Barriers to wider adoption CFBC technology: With around $20 \mathrm{GW}$ operating worldwide, CFBC units can demonstrate significant operating experience. They have the ability to accept a variety of fuels, including a range of coals: from lignites to anthracite, waste coal and biomass. They exhibit low emissions of conventional pollutants and show potential to be designed for oxy-firing. Though there is a need for research, development and demonstration (RD\&D) to progress to higher steam conditions over time, there are no obvious barriers to CFBC other than the size of the market. The major development needs for supercritical CFBC technology are mostly similar to those for SC and USC pulverised coal-fired technology. These are to develop materials with higher temperature and pressure resistances, to improve fabrication technology using these materials; and to accelerate demonstration of large SC units.

\subsection{Integrated Gasification Combined Cycle}

Coal-based integrated gasification combined cycle (IGCC) uses a combination of gas and steam turbines to produce electricity. The gas used to fire the gas turbine is first made by "gasifying" or partially oxidizing the coal to produce a fuel gas, which is then followed by gas cleaning as shown in fig. 1 
Table 1. Major supercritical units - recently commissioned, under construction or planned.

\begin{tabular}{|c|c|c|c|}
\hline Australia & Kogan Creek, 2007, $750 \mathrm{MWe}$ & Netherlands & $\begin{array}{l}\text { Eemshaven, under construction, } \\
\text { 2013, 2x } 800 \mathrm{MWe}\end{array}$ \\
\hline Canada & Genesee Unit 3, 2005, 450 MWe & South Africa & 2011-15, 6×800 MWe \\
\hline China & $\begin{array}{l}\text { Waigaoqiao, 2008, 2×1 } 000 \mathrm{MWe} \\
\text { Yuhuan, 2007-08, 4×1000 MWe } \\
\text { Under construction, } 50000 \mathrm{MWe} \\
\text { Planned by } 2015 \text {->110 } 000 \mathrm{MWe}\end{array}$ & Russia & $\begin{array}{l}\text { Berezovskya, 2011, 800 MWe } \\
\text { Novocherkasskaya, 2012, } 330 \\
\text { MWe,CFB } \\
\text { Petrovskaya, 2012-14, 3×800 MW }\end{array}$ \\
\hline India & $\begin{array}{l}\text { Sipat, 2007-09, 3×660 MWe } \\
\text { Barh, 2009, 3x660 MWe } \\
\text { UltraMega Projects - 2012, } \\
\text { 5×4 000 MWe plants; unit size } \\
660 \mathrm{MWe} \text { or } 800 \mathrm{MWe}\end{array}$ & Germany & $\begin{array}{l}\text { Niederaussem, 2003, } 1000 \mathrm{MWe} \text {, } \\
\text { Lignite } \\
\text { Walsum, 2010, } 750 \mathrm{MWe} \\
\text { Neurath, under construction, 2011, } \\
\text { * USC units } \\
\text { Hamm, Under construction, } 2012\end{array}$ \\
\hline $\begin{array}{l}\text { United } \\
\text { States }\end{array}$ & $\begin{array}{l}\text { 2008, } 545 \mathrm{MWe}, 890 \mathrm{MWe} \\
\text { Oak Grove, Texas, 2009, } 800 \mathrm{MWe} \\
\text { Oak Grove, Texas, 2010, } 800 \mathrm{MWe} \\
\text { Under construction, 2009-12, }\end{array}$ & Poland & $\begin{array}{l}\text { Lagisza, 2009, 460 MWe, CFB } \\
\text { Belchatow, 2010, } 833 \mathrm{MWe}\end{array}$ \\
\hline Italy & $\begin{array}{l}\text { Torrevaldaliga Nord, } 2010,3 \times 660 \\
\text { MWe } \\
\text { Planned by } 2015,3 \times 660 \mathrm{MWe}\end{array}$ & Korea & $\begin{array}{l}\text { Tangjin, 2006, } 2 \times 519 \mathrm{MWe} \\
2008-10,5 \times 500 \mathrm{MWe}, 2 \times 870 \\
\text { MWe }\end{array}$ \\
\hline Mexico & * Pacifico, 2010, $700 \mathrm{MWe}$ & & \\
\hline
\end{tabular}

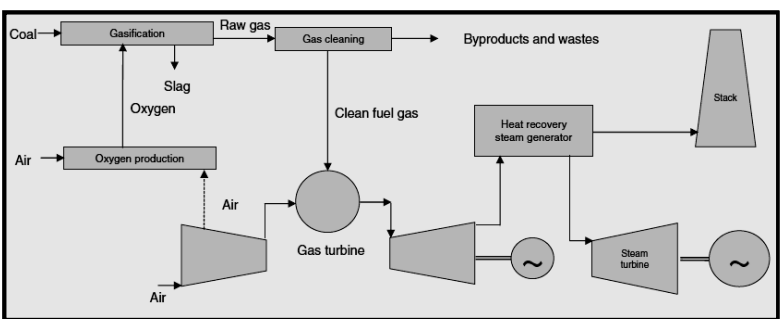

Fig. 1: Major components of an IGCC system without $\mathrm{CO}_{2}$ capture.

The major subsystems within IGCC that have the potential to influence the overall efficiency, cost and reliability, are:

(i) Gasifier - this affects the conversion of carbon in coal to fuel gas

(ii) Gas cleaning system - this affects the emission of pollutant gases and gases harmful to either the environment, the gas turbine or both;

(iii) Oxygen production;

(iv) Gas turbine;

(v) Syngas cooler, heat recovery steam generator, steam turbine cycle.

For details on subsystems, the IEA-2011 report is recommended.

Outlook for coal-based IGCC: Aided by climate change mitigation pressures and technical and cost improvements, IGCC has the potential, in the longer term, to compete with PC combustion technology, the current system of choice for utilities. However, the immediate future of the technology is less certain.
As indicated in Table 2, several IGCC projects have been proposed in Australia, China, the European Union and the United States, with a number of other countries showing interest. Of around $25500 \mathrm{MW}$ IGCC projects proposed worldwide in 2007 , the majority were later cancelled, citing cost escalations and uncertainty in emission regulations. Of note is that $60 \%$ of the projects were in the United States, greatly helped by the provisions of the 2005 Energy Policy Act.

Immediate concerns must be addressed if IGCC is to be more widely deployed. Though proponents of IGCC may point to particular benefits, such as emissions performance or potential for polygeneration, it is still perceived to have as of yet unquantified operating risks. Operation and maintenance costs are less certain as there are few reference plants and little power industry operating experience. Other issues include improving the capital cost and availability of IGCC on all coals.

\section{DEVELOPMENTS IN COAL TREATMENT}

Coal treatment can bring considerable environmental benefits, including reduced emissions of $\mathrm{SO}_{2}, \mathrm{NOx}$, particulates and $\mathrm{CO}_{2}$, through the supply of clean coal of consistent quality to downstream utilization processes.

Coals are extremely heterogeneous, varying widely in their content and properties from country to country; mine to mine, and even from seam to seam. The principle impurities are ash-forming minerals and 
Table 2. Major Coal-based IGCC projects under consideration

\begin{tabular}{|c|c|c|c|c|c|c|}
\hline Project & Location & Coal & $\begin{array}{l}\text { Gasifier } \\
\text { Technology }\end{array}$ & $\begin{array}{l}\text { Gas turbine } \\
\text { and model }\end{array}$ & $\begin{array}{l}\text { Net output } \\
\text { (MWe) }\end{array}$ & Year \\
\hline GreenGen & $\begin{array}{l}\text { Tianjin } \\
\text { China }\end{array}$ & Bit & $\begin{array}{l}\text { Shanghai } \\
\text { boiler; } \\
\text { dry fed } \mathrm{O} 2 \text { blown }\end{array}$ & $\begin{array}{l}\text { Siemens and } \\
\text { Shanghai } \\
\text { Electric } \\
\end{array}$ & $\begin{array}{l}250 \text { - stage } 1 \\
400 \text { - stage } 2\end{array}$ & $\begin{array}{l}\text { Late } 2011 \\
\text { [Stage 1] }\end{array}$ \\
\hline $\begin{array}{l}\text { Dongguan } \\
\text { Taiyangzhou }\end{array}$ & $\begin{array}{l}\text { Guangdong } \\
\text { China }\end{array}$ & Bit & $\begin{array}{l}\text { KBR Transport } \\
\text { Integrated } \\
\text { Gasification }\end{array}$ & Unknown & $\begin{array}{l}120 \text { - stage } 1 \\
800 \text { - stage } 2\end{array}$ & $\begin{array}{l}\text { Late } 2011 \\
\text { [Stage 1] }\end{array}$ \\
\hline Duke Energy & $\begin{array}{l}\text { Indiana } \\
\text { US }\end{array}$ & Bit & $\begin{array}{l}\text { GE } \\
\text { Slurry-fed O2 } \\
\text { blown }\end{array}$ & $\begin{array}{l}\text { GE } \\
\text { Frame 7B }\end{array}$ & 618 & 2012 \\
\hline $\begin{array}{l}\text { Nuon } \\
\text { Magnum }\end{array}$ & $\begin{array}{l}\text { Eemshaven } \\
\text { Netherlands }\end{array}$ & $\begin{array}{l}\text { Bit } \\
\text { Biom }\end{array}$ & Shell & $\begin{array}{l}\text { MHI } \\
\text { 3xM701F4 }\end{array}$ & 2012 & $\begin{array}{l}\text { [CCGT as } 1^{\text {st }} \\
\text { phase] }\end{array}$ \\
\hline $\begin{array}{l}\text { Excelsior } \\
\text { Energy }\end{array}$ & $\begin{array}{l}\text { Minnesota } \\
\text { US }\end{array}$ & Lig/PetCoke & $\begin{array}{l}\text { ConocoPhillips } \\
\text { Slurry-fed O2 } \\
\text { blown }\end{array}$ & $\begin{array}{l}\text { Siemens } \\
2 \mathrm{xS} 5000 \mathrm{~F}\end{array}$ & 620 & $\begin{array}{l}2014 \\
\text { [No PPA, as } \\
\text { yet] }\end{array}$ \\
\hline $\begin{array}{l}\text { Southern } \\
\text { Company }\end{array}$ & $\begin{array}{l}\text { Mississippi } \\
\text { US }\end{array}$ & Lig & $\begin{array}{l}\text { KBR Transport } \\
\text { Integrated } \\
\text { Gasification }\end{array}$ & $2 \mathrm{x}$ 'F' Class & 582 & 2014 \\
\hline $\begin{array}{l}\text { Texas Clean } \\
\text { Energy } \\
\text { Project }\end{array}$ & $\begin{array}{l}\text { Texas } \\
\text { US }\end{array}$ & Sub-bit & Siemens & Siemens & 380 & 2015 \\
\hline $\begin{array}{l}\text { Wandoan } \\
\text { Power }\end{array}$ & $\begin{array}{l}\text { Queensland } \\
\text { Australia }\end{array}$ & Bit & GE & GE & 334 & 2016 \\
\hline $\begin{array}{l}\text { Osaki } \\
\text { CoolGen }\end{array}$ & Japan & Sub-bit & Hitachi & Hitachi & 140 & 2017 \\
\hline $\begin{array}{l}\text { Hydrogen } \\
\text { Energy } \\
\text { California }\end{array}$ & $\begin{array}{l}\text { California } \\
\text { US }\end{array}$ & Bit/pet coke & GE & $\begin{array}{l}\text { GE } \\
\text { Frame 7F }\end{array}$ & 250 & 2018 \\
\hline $\begin{array}{l}\text { American } \\
\text { Electric } \\
\text { Power } \\
\end{array}$ & $\begin{array}{l}\text { Ohio } \\
\text { US }\end{array}$ & Bit & $\begin{array}{l}\text { GE } \\
\text { Slurry-fed O2 } \\
\text { blown }\end{array}$ & $\begin{array}{l}\text { GE } \\
\text { Frame 7B }\end{array}$ & 630 & $\begin{array}{l}\text { [Project on } \\
\text { hold] }\end{array}$ \\
\hline $\begin{array}{l}\text { Taylorville } \\
\text { Energy } \\
\text { Center }\end{array}$ & $\begin{array}{l}\text { Illinois } \\
\text { US }\end{array}$ & Bit & Siemens & GE & 600 & $\begin{array}{l}\text { [Project on } \\
\text { hold] }\end{array}$ \\
\hline
\end{tabular}

sulphur. Some are interspersed through the coal seam, some are introduced by the mining process, and some -principally organic sulphur, nitrogen and some mineral salts -are bound organically to the coal

These impurities affect the properties of the coal and the combustion process, including the nature of the flue gas emissions and the combustion residues. The coal beneficiation or preparation process, which also often goes by the terms coal cleaning or coal washing, is aimed at separating and removing the impurities to the extent possible and economically feasible. Coal beneficiation aims to separate the coal from the impurities mainly by exploiting differences in density. Physical coal preparation processes target inorganic impurities and do not remove those organically bound to the coal. Sulphur is a prime target to reduce sulphur dioxide emissions following combustion. It is present both as an inorganic component (pyrite particles), and organically bound.

\subsection{Coal Beneficiation}

A number of countries, notably India, China, Czech Republic, Poland, South Africa, Romania and Turkey use high-ash coals for power generation. During the mining operation, ash and other extraneous matter are also extracted with the coal. Coal beneficiation is a process that improves the quality of coal by reducing the extraneous matter or reducing the associated ash, or both. The two basic processes of beneficiation (Satyamurty, 2007) are dry de-shaling and wet process. In dry de-shaling, the non-coal matter or shaly coal is removed using no liquid media. However, in wet process, coal is crushed and put in a liquid media (usually water) of adjustable specific gravity to separate the lighter coal (with low-ash content) from 
heavier coal (with high ash content). The rejects from the wet process also contain carbonaceous matter.

Major benefits of coal beneficiation: It results in savings in the capital and operating costs of the power plant, particularly the boiler, coal handling and ash handling systems. The cost of power generation may also be reduced if the washed coal increases the plant load factor and the washery rejects are utilized efficiently in fluidized bed boilers.

R\& D needs for coal beneficiation: It is important to develop new technologies to make significant reductions in ash content through coal beneficiation. Increasing the yield of low-ash coal and reducing the consumption of water are the two major challenges to be overcome by the wet process for coal beneficiation.

\subsection{Developments in Coal Drying}

Low-rank coals containing high-moisture (30 to $70 \%$ on as-received weight basis) represent a significant resource worldwide. An estimated 45\% of the world's coal reserves are lignites (brown coal). These are inexpensive, low in ash and sulphur reserves, but have a high-moisture content of up to $65 \%$ on an as-received basis. Brown coal represents an important source of power generation in several countries, including Australia, Germany, Greece, Poland, Russia, Turkey and the United States.

The needs for coal drying: Coal pre-drying is an important step towards improving the efficiency of both existing and new power plants using high-moisture coals. In general the efficiency of a unit using coal drops by about 4 percentage-points and 9 percentage-points when coal moisture content increases from 10 to $40 \%$ and $60 \%$ respectively. Apart from efficiency reduction, high moisture increases coal handling feed rate, demands more auxiliary power for coal-handling systems and pulverisers, and leads to higher plant operating and maintenance costs.

\section{RECOMMENDATIONS}

(i) Large-scale supercritical pulverised coal plants are commercially available and cost effective. Strong consideration should be given to the introduction of policies that markedly reduce the future construction of sub-critical plant for new build.

(ii) Following the successful commissioning of the first supercritical CFBC at Lagisza (Poland), it should serve as an example for future CFBC plants. In fact, both China and Russia now have programmes to construct supercritical CFBC units.

(iii) Maximizing plant efficiency is highly desirable when employing CCS. Efficiency gains from upgrading sub-critical units are limited. To achieve efficiencies higher than $40 \%$ (LHV, net), operation with supercritical steam conditions is necessary. If, at some future time, CCS is to be applied to most coal-fired plant, policies will need to address the status of less efficient power generation.

(iv) A significant part of the world's coal reserves comprises brown coal or lignites, often associated with high moisture content. This can lead to a penalty of between 4 and 9 percentage-points in plant efficiency. RWE employs a novel coal-drying process at Niederaussem Unit K, where an efficiency of $43.5 \%$ (LHV, net) has been achieved. Improvements under development may lead to an increase of a further 4 percentage-points. This work sets a benchmark for what may be achieved using low-grade coals.

\section{CONCLUSIONS}

Coal is an important source of energy for the world, particularly for power generation. However, to play its role in a sustainable energy future, its environmental (harmful emissions) footprint needs to be reduced; using coal more efficiently is an important first step. Where economic and regulatory conditions exist which shift this balance consistently in favor of higher efficiency and lower emissions, improvements become a commercial imperative and will become a normal part of operating a competitive business. The development of supercritical steam cycles with progressively higher steam temperatures, combined with modern plant design and automation, provides significant potential for efficiency improvement and mitigation of $\mathrm{CO}_{2}$ emissions compared to existing coal-fired plant. These improvements will be realized through the progressive replacement of existing assets with reference to leading practice plant designs. Nevertheless, the greatest reduction in specific $\mathrm{CO}_{2}$ emissions from coal-fired plant will eventually be realized through the application of carbon capture and storage (CCS) technology. Consideration of the basic efficiency of the power plant will be a major factor in the economic viability of CCS. Potential exists for even greater $\mathrm{CO}_{2}$ reductions where CCS is applied to coal.

\section{ACKNOWLEDGEMENT}

It is acknowledged that this article is an abbreviated and restructed form of the IEA (International Energy Agency) report 2011.

\section{REFERENCES}

[1] International Energy Agency Report 2011. 